\title{
THE EFFECT OF PHYSICAL FEED STRUCTURE ON THE COMMERCIAL BROILERS' PERFORMANCE
}

\author{
Lumturi Sena ${ }^{1}$, Dallendyshe Peti ${ }^{1}$, Nedeljka Nikolova ${ }^{2}$ \\ ${ }^{1}$ Department of Animal Production, Agricultural University of Tirana, Albania \\ ${ }^{2}$ University "Ss. Cyril and Methodius" in Skopje, Institute of Animal Science, \\ Bul. Ilinden 92-a, Skopje, Skopje, Republic of Macedonia \\ lumturisena@yahoo.com
}

\begin{abstract}
The effect of the physical structure of broilers' feed (pelleted vs. mash feed) on their performace parameters was studied in this trial. Two groups of 300 commercial broilers each (ROSS-308) were created. The control group was fed with mash feed, while the experimental gruop was fed crumbled feed during the first three weks (0-3 weeks) and then pelleted feed until the end of the life (slaughtering). Both feeds were of identical composition and formulas, as well as same environmental and management conditions were provided for both groups. At the end of this trial, it was concluded that the broilers fed with pelleted feed had a $6-7 \%$ higher body weight, a higher carcass weight and a higher meat yield $(\mathrm{P}<0.01)$. The same conclusion was drawn on the flock uniformity. The pelleted feed fed group demonstrated a more efficient feed conversion rate $(1.81 \mathrm{~kg}$ feed $/ \mathrm{kg}$ live weight). These results clearly demonstrate the advantages of using the crumbled/pelleted feed vs the mash one, since the production parameters of commercial broilers show it.
\end{abstract}

Key words: broilers; crumbles; live weight; mash feed; pellets

\section{ВЛИЈАНИЕ НА ФИЗИЧКА СТУКТУРА НА СМЕСКАТА ВРЗ КОМЕРЦИЈАЛНИТЕ ПЕРФОРМАНСИ НА БРОЈЛЕРИТЕ}

Во овој експеримент беше проучувано влијанието на физичката структура на смеската за бројлери (пелетирана во однос на ситно мелена) врз нивните перформанси. Експериментот беше спроведен врз две групи од по 300 комерцијални бројлери (ROSS-308). Контролната група беше хранета со мелена смеска додека експерименталната група во првите три недели (0-3 недели) беше хранета со крупно мелена смеска, а потоа со пелетирана смеска се до крајот на животот (до колењето). Двете смески беа со идентичен состав и формула, а исто така и двете групи на бројлери беа чувани и одгледувани во иста средина и во исти услови. На крајот од експериментот беше заклучено дека бројлерите хранети со пелетирана смеска имаат за 6-7\% поголема жива маса, поголема маса на трупот и имаат поголем принос на месо $(\mathrm{p}<0.01)$. Истиот заклучок беше донесен и во однос на униформноста на јатото. Групата хранета со пелетирана смеска покажа поголема ефикасност во однос на степеност на конверзија на храната $(1,81 \mathrm{~kg}$ смеска $/ \mathrm{kg}$ жива маса). Овие резултати јасно укажуваат на предноста за користење на крупно мелена/пелетирана храна во однос на ситно мелената храна кај комерцијалните бројлери.

Клучни зборови: бројлери; крупно мелена храна; жива маса; ситно мелена храна; пелети

\section{INTRODUCTION}

Feed comprises about $60-70 \%$ of the total cost of broiler meet (Banerjee, 1998). The physical form of feed (mash vs. pelleted) plays an important role in the production of broilers' meat and affects both the cost of meet and the performance of broiler production. The pelleted feed is a better alternative compared to the mash form of it. It consists of mechanical pressing of the mash feed into pellets, which are more compact as such (Banerjee, 1998). The main advantage of using pelleted feed consists in the fact that it minimizes feed losses, while its disadvantage is that it is about $10 \%$ more expensive than mash feed. Asha Rajini et al. (1998) reported that the pellets influence to im- 
prove the Feed Conversion Rate for chicks up to 6 weeks. On the other hands Moran (1990), studied and conluded that the use of pelleted feed improved chicken's body weight.

Recently broilers growers successfully used crumbled feed. Choi et al. (1986), concluded that the crumbled feed fed broilers consumed more feed. Application of each physical structure of feed has several advantages and disadvantages. Efficiency, digestibility, and feed conversion for each form of feed used are also different.

As far as the above statement is concerned, a modest study was carried out, in order to be able to test the effect of physical structure of feed (mash, crumbled and pelleted) on broilers' performance.

So with this trial we aimed to observe the impact of using the pelleted feed on the dynamics of growth, the homogenity of the flock, FCR, and other indicators of broiler production.

\section{MATERIAL AND METHODS}

The experiment was conducted in a broiler farm in Fier district. The flock was made of ROSS308 hybrid chickens. Based on the principle of comparative analogy from the standpoint of breed, age, productivity and health status, 2 groups of 300 birds each, were established. Throughout the trial period the chicks were kept in the same environment (house), grown in the floor (horizontal), and under the same environmental conditions, equal treatment and service.

During the growth period, both groups were fed with two kinds of feeds (starter \& grower 0-3 weeks and finisher 4-6 weeks). But while the control group was fed with mash feed, the experiment one was fed crumbled feed for the first stage (0-3 weeks) and pelleted one for the finisher stage. All the feed was produced at the "AGROTEK" Feedmill.

The experiment was conducted in two phases under the following methodical scheme:

\section{Table 1}

\section{Methodical scheme of the experiment}

\begin{tabular}{lccc}
\hline \hline $\begin{array}{l}\text { Stages of } \\
\text { experiment }\end{array}$ & $\begin{array}{c}\text { Time duration of } \\
\text { each stage (in weeks) }\end{array}$ & \multicolumn{2}{c}{$\begin{array}{c}\text { Control } \\
\text { Feed }\end{array}$} \\
\hline Starter \& Grower & $0-3$ & Mash & Crumbled \\
Finisher & $4-6$ & Mash & Pelleted \\
\hline \hline
\end{tabular}

Table 2

Feed formulas and respective composition applied for both groups (\%)

\begin{tabular}{lcc}
\hline \hline Ingredients & $\begin{array}{c}\text { Starter \& Grower } \\
\text { Stage Feed }\end{array}$ & Finisher Feed \\
\hline Corn 8.5\% CP & 38.9 & 40.4 \\
Soybean oil & 2.5 & 4.1 \\
Wheat 12\% CP & 20.0 & 25.0 \\
Soya Hipro 48\% CP & 33.8 & 26.7 \\
Limestones 36 & 1.2 & 0.9 \\
Dicalphos 18.5P/26CA & 1.1 & 0.4 \\
KBFP 2.5 & 0.0 & 2.5 \\
KBSP 2.5 Sa & 2.5 & 0.0 \\
\hline Total & 100 & 100 \\
\hline & Calculated composition & \\
E M (Kcal) & 3000 & 3196.75 \\
Crude protein (\%) & 22.64 & 19.96 \\
Crude fat (\%) & 5.14 & 6.74 \\
Crude fiber (\%) & 3.02 & 2.87 \\
Dlys-P (\%) & 1.05 & 0.89 \\
dMeth-P (\%) & 0.44 & 0.39 \\
dM +C-P (\%) & 0.74 & 0.67 \\
Calcium (\%) & 0.90 & 0.61 \\
\hline P.Total (\%) & 0.60 & 0.45 \\
\hline \hline
\end{tabular}

The following indicators were recorded:

- Day old chicks' body weight at the beginning of the experiment, which was monitored every week until the end of the experiment. For this purpose, $5 \%$ ( 15 chickens) of the randomly selected chicken were weighed at the same day and time before eating.

- Flock uniformity: For this purpose the $\mathrm{Cv}$ was calculated based on the relevant tables of Ross Guide and based on this, the flock's uniformity was evaluated. The Coefficient of variation was calculated as follows:

$$
\begin{gathered}
C v \%=[\text { standard deviation }(\mathrm{g}) \div \text { average body } \\
\text { weight }(\mathrm{g})] \times 100
\end{gathered}
$$

Feed consumption per each group (in $\mathrm{kg}$ ). At the end of each period, the quantity of the used feed by each group was calculated. These data were used to calculate the Feed Conversion Rate per kg of live weight. 
Calculation of the total feed consumption/bird and per kg of gained weight.

Carcass traits: At the end of the experiment, 10 broilers/group were sampled and the following indicators were measured and/or calculated: live weight, carcass weight, meat yield, heart weight, liver weight, the gizzard weight. All chicks were manually slaughtered, in order to get a more accurate assessment of the above-mentioned indicators.

For each stage of growth (starter+grower and finisher) the relevant Vitamin \& Mineral Premix was applied. The obtained results according to described methodology were statistically processed through the descriptive statistics methods and ANOVA.

\section{RESULTS AND DISCUSSION}

\section{1) Body weight}

In Table 3, the average body weight, monitored week after week for both groups is evidenced.

At the table above, it can be seen that starting from the fourth week, the group fed with crumbled feed (during the first stage of growth) and pellted feed (during the second stage) shows the highest body weight. These findings regarding the superiority of the experimental group can be synthesized in the figures as following: in the second week 7.6 $\mathrm{g}$, or $2.1 \%$ more, in the third week, $34.3 \mathrm{~g}$, or $4 \%$ more, in the fourth week, $109 \mathrm{~g}$, or $9 \%$. Moreover, in the fifth week $197.7 \mathrm{~g}$, or $11.2 \%$ more, in the sixth and the last week $176.3 \mathrm{~g}$, or $6.7 \%$ more.

These results are similar to studies carried out by Preston (2000) and Munt, etc. (1995), who presented a significantly weaker performance in birds fed with mash feed. Kim and Chung (1994), showed that birds fed with mash feeds, at the age of 41 days had a lower body weight than those fed with crumbled and pelleted feed. Reece etc. (1985), Auckland and Fulton (1972), Runnels, etc. (1976) and Choi, etc. (1986) also claimed that the crumbled feed gave better results in the growth of broiler than that in other forms.

Table 3

Average body weight ( $g$ ) of broiler birds according to their age in weeks for each group

\begin{tabular}{cccc}
\hline \hline Week & Control & Experiment & $\begin{array}{c}\text { Level of } \\
\text { Significance }\end{array}$ \\
\hline Day 1 & $46.73 \pm 4.184$ & $46.67 \pm 5.589$ & NS \\
1 & $181.33 \pm 5.815$ & $180.87 \pm 9.433$ & NS \\
2 & $358.67 \pm 9.537$ & $366.33 \pm 9.537$ & NS \\
3 & $859.67 \pm 58.872$ & $894.00 \pm 40.143$ & NS \\
4 & $1211.33 \pm 86.344$ & $1320.33 \pm 82.494$ & S \\
5 & $1761.33 \pm 184.405$ & $1959.00 \pm 224.350$ & S \\
6 & $2617.00 \pm 162.698$ & $2793.33 \pm 123.554$ & S \\
\hline \hline
\end{tabular}

Note: The sign "S" indicates that the differences between groups were statistically significant, while "NS" indicates the fact that the differences are statistically non-significant.

\section{2) Uniformity of live weight (CV\%)}

In our study, for both groups after each weighing of the birds live weight uniformity is also estimated. Based on "ROSS broilers Management Guide, 2009", the flock uniformity for each group was also evaluated

Table 4

Comparison of uniformity of birds among the groups by weeks

\begin{tabular}{cccc|ccc}
\hline \hline \multirow{2}{*}{ Week } & \multicolumn{3}{|c|}{ Control } & \multicolumn{3}{c}{ Experiment } \\
\cline { 2 - 6 } & $\mathrm{M} \pm \mathrm{SD}$ & $\mathrm{Cv}(\%)$ & Uniformity (\%) & $\mathrm{M} \pm \mathrm{SD}$ & $\mathrm{Cv}(\%)$ & Uniformity (\%) \\
\hline Day 1 & $46.73 \pm 4.184$ & 8.95 & $(73.3)$ & $46.67 \pm 5.189$ & 11.13 & $(63.7)$ \\
1 & $181.33 \pm 5.815$ & 3.20 & $($ over 95) & $180.87 \pm 9.433$ & 5.22 & $(95.4)$ \\
2 & $358.67 \pm 9.537$ & 2.66 & $($ over 95) & $366.33 \pm 9.537$ & 2.60 & (over 95) \\
3 & $859.67 \pm 58.872$ & 6.85 & $(84.7)$ & $894.00 \pm 40.143$ & 4.49 & $\mathbf{( 9 5 . 4 )}$ \\
4 & $1211.33 \pm 86.344$ & 7.13 & $(84.7)$ & $1320.33 \pm 82.494$ & 6.25 & $\mathbf{( 9 0 . 4 )}$ \\
5 & $1761.33 \pm 184.405$ & 10.47 & $(68.3)$ & $1959.00 \pm 194.350$ & 9.92 & $(68.3)$ \\
6 & $2617.00 \pm 162.698$ & 6.22 & $(90.4)$ & $2793.33 \pm 123.554$ & 4.42 & (over 95) \\
\hline \hline
\end{tabular}


As shown in the above table, both flocks of birds under this trial, didn't have a satisfactory homogeneity. During the first and the second week, this homogeneity is significantly improved by taking the optimal value for both groups. In subsequent weeks the experimental group noted the superiority for this indication. An exception is made in the fifth week, where surprisingly the two groups had an average uniformity. So we can conclude that although both groups observed a satisfactory uniformity, the group fed with pelleted feed seems to be more superior for this index. High flock uniformity, gives growers better chanses of efficient feed use. Many managers recognize the value of $80 \%( \pm 10 \%)$ or $85 \%( \pm 15 \%)$ as a standard of uniformity (S. Leeson, J. D. Summers, 2000).

\section{3) Weight gain}

Table 5 shows the average weight gain per bird per week and per day.

\section{Table 5}

Weekly and daily weight gain for birds of each group by weeks

\begin{tabular}{ccccc}
\hline \hline & \multicolumn{2}{c}{ Control } & \multicolumn{2}{c}{ Experiment } \\
\cline { 2 - 5 } Week & $\mathrm{g} /$ bird/week & $\mathrm{g} /$ bird/day & $\mathrm{g} /$ bird/week & $\mathrm{g} /$ bird/day \\
\hline 1 & 134.6 & 19.23 & 134.2 & 19.17 \\
2 & 177.34 & 25.33 & 185.46 & 26.49 \\
3 & 501.00 & 71.57 & 527.67 & 75.38 \\
4 & 351.66 & 50.24 & 426.33 & 60.90 \\
5 & 550.00 & 78.57 & 638.67 & 91.24 \\
6 & 855.67 & 122.24 & 834.33 & 119.19 \\
\hline \hline
\end{tabular}

If the gain (weekly and daily) for the first week was similar for both groups, we can not say the same for the coming weeks. Respectively for the third, fourth and fifth week the superiority of the experimental group can be easily noted. This fact is significant, since it was also clearly evidented at the time of the slaughter. So, feeding the broilers with crumbled and later on pelleted feed has shown its effect, through making possible higher gain and eventually, higher body weight at the end of growth.

Sihna et al, (1994) and Reece et al, (1985) reported that mash feed application, leads to a lower gain compared to the crumbled one. Asha Rajini et al, (1998), Deaton et al (1992), Kamar et al (1974), and Bertechini et al (1992) reported that birds fed with pelleted feed reached higher body weight than those fed on mash feeds. Allred et al (1996) also reported that birds grew faster when fed with crumbled and/or pelleted feed compared with those who received the same diet but in a mash form.

\section{4) Feed conversion (FCR)}

\section{Table 6}

Feed conversion according to the age in weeks for each group

\begin{tabular}{cccccc}
\hline \hline Week & Control & Exsperiment & Value of P & F & F Critical \\
\hline 1 & 1.00 & 1.00 & & & \\
2 & 1.49 & 1.43 & & & \\
3 & 0.88 & 0.83 & & & \\
4 & 2.68 & 2.21 & & & \\
5 & 2.96 & 2.55 & & & \\
6 & 2.77 & 2.84 & & & \\
Total & $\mathbf{1 . 9 6} \pm \mathbf{0 . 9 5}$ & $\mathbf{1 . 8 1} \pm \mathbf{0 . 8 4}$ & 0.78 & 0.09 & 4.96 \\
\hline \hline
\end{tabular}

Table 6, clearly indicates that the group of experiment indicates a tendency towards the improvement of feed conversion rate, starting from the second week of life until the end of the growth cycle. For the entire growth period the average feed saving results to be $0.15 \mathrm{~g}$ feed $/ \mathrm{g}$ live weight, or $7.7 \%$ less feed per unit of weight.

As stated in the Ross's Broilers Management Guide, 2009, we see that the coefficient of utilization of feed has a value of 1.75 , while we see that the best rate achieved in the experiment group was 1.81 , or $3.4 \%$ higher than standard. A more accurate correction of microclimate parameters, particularly temperature and a better ratio between air temperature and humidity, could contribute to reducing feed consumption and therefore to improvement of the economic efficiency.

According to Moran (1990) and Reece etc. (1986), the pelleted feed had a better efficiency of feed utilization/conversion than the mash feed. Howlider and Rose (1992) concluded that the pelleted feed increased the extent of conversion with $5.9 \%$. In the same way, Reece (1984) reported that the use of crumbled feed improved the conversion rate to a level of $1.5 \%$. 


\section{5) Carcass traits}

Table 7

Slaughtered sample analysis of both at the end of the experiment $(M \pm S D)$

\begin{tabular}{lccccc}
\hline \hline Parameters & Control & Experiment & Value of P & F & F Critical \\
\hline Body weight (g) & $2492,5 \pm 318,83$ & $2773,5 \pm 176,29$ & 0.025 & $\mathbf{5 . 9 4 9}$ & 4.414 \\
Carcass weight (g) & $1782 \pm 230,65$ & $2055,5 \pm 130,97$ & 0.004 & $\mathbf{1 0 . 6 3 2}$ & 4.414 \\
Meat yield (\%) & $71,51 \pm 2,20$ & $74,13 \pm 1,69$ & 0.008 & $\mathbf{8 . 9 1}$ & 4.414 \\
Heart weight (g) & $14,5 \pm 2,84$ & $15,5 \pm 2,84$ & 0.441 & 0.621 & 4.414 \\
Liver weight (g) & $70 \pm 12,47$ & $72 \pm 10,59$ & 0.704 & 0.144 & 4.414 \\
Stomach (proventriculus) weight (g) & $7,5 \pm 2,64$ & $8,5 \pm 2,42$ & 0.388 & 0.783 & 4.414 \\
Gizzard weight (g) & $37 \pm 5,37$ & $37,5 \pm 6,77$ & 0.857 & 0.033 & 4.414 \\
Guts' weight (g) & $168,5 \pm 34,16$ & $186,5 \pm 34,24$ & 0.255 & 1.385 & 4.414 \\
Abdominal fat (g) & $42.37 \pm 5,42$ & $49.92 \pm 6,01$ & 0.852 & 0.031 & 4.414 \\
\hline \hline
\end{tabular}

The above table clearly shows the difference in weight between the two groups. The difference is statistically signifficant in favor of the experiment group. The same thing is observed for carcass weight, even higher differences. In birds of the experiment group the meat yield is significantly improved at a rate of $2.62 \%$. In terms of weight of internal organs, mentionning the weight of the heart, stomach, liver, gizzard, abdominal fat and intestinal weight, differences are not statistically signifficant. Of course, slightly higher weight was observed in the relevant broilers fed with pelleted feed, but these can only be considered a trend.

\section{CONCLUSIONS}

Broilers fed with crumbled and later on pelleted feed showed a better peformance as far as the body weight and daily gain, compared with the ones fed with mash feed;

Broilers fed with pelleted feed showed a tendency for a better flock uniformity;

Application of crumbled/pelleted feed in broilers influenced towards a slight improvement of the Feed Conversion Rate (FCR).

\section{REFERENCES}

[1] Allred J. B., Jensen, L. S., Ginnis J. M. C.. (1996). Studies on the growth promoting effect induced by pelleting feed. Poult. Sci., 35: 1130-1133.
[2] Asha Rajini R., Kumararaj, R., Narahari, D., Ravindran, R., Sundaresan, K. (1998): Influence of season, form of feed, dietary energy, age and sex on carcass traits of broilers. Ind. J. Poult. Sci., 33: 346-348.

[3] Auckland J. M., Fulton, R. B. (1972): The effect of dietary nutrient concentration, crumbles versus mash and age of dam on the growth of broiler chicks. Poult. Sci., 51: 1968-1975.

[4] Banerjee G. C. (1998): Poultry. Third edition, Oxford and IBH Publishing Co. Pvt. Ltd. Calcutta, pp: 120-121.

[5] Bertechini A. G., Rostagno, H. S., Oliveira, A. I. G. (1992): Effect of nutrient concentration on performance of broilers. Poult. Abst., 18: 2965.

[6] Choi J. H., So, B. S., Ryu, K. S., Kang, S. L. (1986): Effects of pelleted or crumbled diets on the performance and the development of the digestive organs of broilers. Poult. Sci., 65, 594-597.

[7] Deaton J. W. (1992): The effect of meal feeding on small intestine weight. Poult. Sci., 71, 1807-1810.

[8] Howlider M. A. R., Rose, S. P. (1992): The Response of growing male and female broiler chickens kept at different temperatures to dietary energy concentration and feed from. Anim. Feed Sci. Tec., 39, 71-78.

[9] Kamar G. A. R., Akheireldin, M. A., El-Difrawi, A. F., Chany, M. (1974): A comparison between pelleted and mash feeding for growing chicks. Egyp. J. Anim. Prod. 14: 129-135.

[10] Kim, Hyoung Ho, Chung, Yuen Hoo (1994): The effects of crumbles, pelleted and extruded feed on the performance of broiler chicken. Sustainable Animal Production and the Environment, 3: 211-212.

[11] Leeson S., Summers J. D. (2000): Broiler Breeder Production. 271-274

[12] Moran E. T., Jr. (1990): Effect of pellet quality on the performance of meat birds. Poult. Abst., 16, 2875.

[13] Munt R. H. C., Dingle, J. G., Sumpa, M. G. (1995): Growth, carcass composition and profitability of meat 
chickens given pellets, mash or free choice diet. $\mathrm{Br}$. Poult. Sci., 36: 277-284.

[14] Preston C. M., Mc Cracken, R. J., Allister, A. Mc. (2000): Effect of diet form and enzyme supplementation on growth, efficiency and energy utilization of wheat based diets for broilers. Br. Poult. Sci., 41: 324-331.

[15] Reece F. N., Lott, B. D., Deaton, J. W. (1984): The effects of feed form, protein profile, energy level, and gender on broiler performance in warm $\left(26.7^{\circ} \mathrm{C}\right)$ environments. Poult. Sci. 63 (10), 1906-11.

[16] Reece F. N., Lott, B. D., Deaton, J. W. (1985): The effect of feed form, grinding method, energy level, and gender on broiler performance in a moderate $\left(21^{\circ} \mathrm{C}\right)$ environmenti. 64, 1834-1839.
[17] Reece F. N., Lott, B. D., Deaton, J. N. (1986): Effects of environmental temperature and corn particle size on response of broilers to pelleted feed. Poult. Sci., 65, 636641.

[18] Ross Broiler Management Manual. (2009): Technical Services.

[19] Runnels T. D., Malone, G. W., Klopp, S. (1976): The influence of feed texture on broiler performance. Poult. Sci., 55, 1958-1961.

[20] Sinha S. C., Digvijoi Singh, Pandita, N. N. (1994): Effect of feeding grower mash ration on the performance of broilers. Poultry Today and Tomorrow, 4 (1/2) 26-30. 